\title{
CRUSTAL ADJUSTMENT IN THE UPPER MISSISSIPPI VALLEY
}

\author{
BY CHARLES ROLIIN KEYES
}

(Presented before the Society December 29, 1898)

\section{CONTENTS}

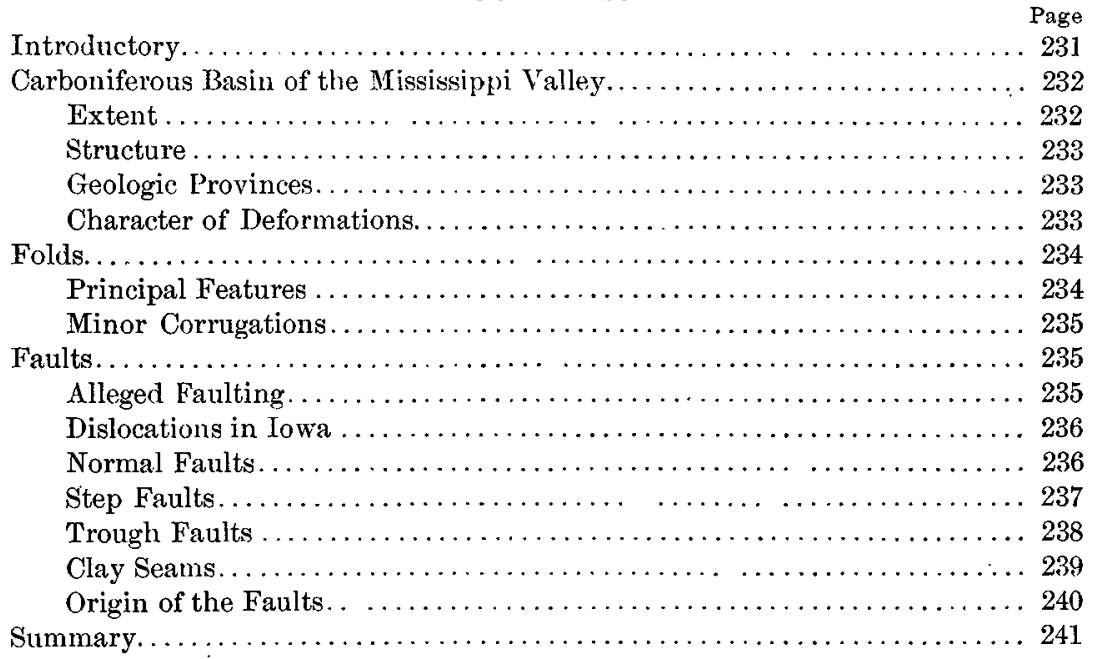

INTRODUCTORY.

The effects of orogenic movements so obvious everywhere in all mountainous regions rapidly lose their more salient characteristics as the distance increases from the heart of the system to the more level, plain-like districts above which they rise. In the lowland plains, such as exist in the Mississippi basin, the corrading power of running water is reduced to a minimum, and profound secular decay or heavy glacial accumulations obscure almost completely everything except the most prominent structural features. Indications of low folds or shallow synclines are often visible in this region, but dislocations of strata are rarely found. That the latter are much more frequent than is perhaps generally supposed, 
subsequent considerations will show. The phenomena here recorded apply more especially to the western interior coal basin occupied in part by Iowa and Missouri, as in this district most of the observations were made.

\section{Carboniferous Basin of the Mississippi Valley.}

Extent.-The broad undulatory plain which occupies the central portion of the American continent, stretching out from the base of the Appalachians to the foot-hills of the Rocky mountains, makes up the principal portion of what is known as the Continental Interior region. It spreads out in one direction for more than nine hundred miles and in another over twelve hundred. Its superficial contents are upward of one million square miles, or more than one-third of the entire areal mileage of the United States. This vast expanse of country, whose sur. face is unbroken by mountains and whoze borders are untouched by the waters of the sea, has been aptly designated a great basin. The Great Mississippi basin it is called, from the majestic river, the "Father of Waters," which flows centrally through it.

The region may be properly regarded as a wide stretch of lowland sloping gently in all directions from the margins toward the center and southward. The "Great Plains " form the western portion of the region; the rolling prairies of the "Upper Mississippi" the median part; the fertile valley of the Ohio and the Cumberland plateau the eastern section. No marked contrasts of altitude break the surface relief of the Mississinpi basin. The lowest point, in the south-central part, is about four hundred feet above tide level; the highest places are on the northern and western margins, where the mean elevation is not far from two thousand feet.

The contrasts of relief to be noted in considering the Interior basin are not those between different parts of the plain itself, but those between the basin as a whole and the region immediately around it. Beyond the boundaries in nearly every direction a mountainous physiognomy is presented. The Appalachians on the east and southeast, the Rocky mountains on the west, the highlands of the Great lakes region northward, all stand out sharply against the country they surround. They all tell of powerful dynamic action which has been at work elevating broad stretches of territory; of continental movements which have operated on a grand scale.

On the whole, erosive agencies have not acted vigorously since the deposits of the Mississippi valley were originally laid down in the old Carboniferous seas. Through most of the long period, from the time when the beds were first raised above the level of the waters of the great 
interior sea at the close of the Carboniferous age to the present date, the vast region must have been nearly the same level lowland that it. is today; a plain whose surface has remained nearly at baselevel for ages, sometimes rising slightly, sometimes sinking a little, but never oscillating far either one way or the other.

Structure.-Great as is the difference between the broad central area of low lying plains and its high serrated borders, there is a diversity of structural features in the geologic details of each of the two districts as distinct and as far removed from one another in character as are the two widely separated types of surface sculpture. On the one hand, throughout the marginal region of the interior basin the elevation of the land has been accompanied by violent disturbances in the strata-folding, crumpling, breaking, grinding the once horizontal beds until now they lie at high angles, with upturned edges everywhere exposed to the swift ravages of nature's destructive agencies. The bold, rugged contours of the mountain surface thus disclose the complicated structure of rocky beds beneath. On the other hand, the lowland plain presents its strata spread out in broad, nearly level sheets much in the same position as when they were first laid down. Although made up almost entirely of sediments dating back in their origin to old Paleozoic times, it is indeed quite remarkable that, formed at a period remote even in geologic units of time, the structural changes should be no greater than they are and that the region should still retain over the greater part of its extent the same simplicity of geologic structure that is found today among the modern depositions of the coastal plains which fringe the great land areas of the globe. The hypsometric changes over the whole region have been, therefore, of the character of continental elevation and depression.

Geologic Provinces.-The present boundaries of the Mississippi valley form approximately the limits of an area which in Carboniferous times had a development peculiarly its own and in a great measure unaffected by events transpiring in neighboring districts. The origin and deposition of its strata, the lithologic characters of its beds, and the succession and evolution of its faunas were wholly independent of the surrounding areas. In short, the Carboniferous basin of the Mississippi valley represents, in every sense of the word, what in geology is called a "geologic province."

Character of Deformations.-The great economic value of the coal-bearing formation of the Mississippi province has directed particular attention to its geology. Within the limits of the region it may now be said that the Coal Measures have received more careful attention than any other of the geologic formations represented; but at the same time, for 
this very reason, the stratigraphic importance of the formation has been greatly overestimated. It has led to the attachment of far too much significance to really trivial characters, which, though they may be quite conspicuous in themselves, are of comparatively small value. Features which in other formations would be entirely overlooked, in connection with coal seams become greatly magnified on account of their bearing upon the expense of mining. Among these factors may be mentioned the various kinds of folds or flexures, faults, slips and "cut-outs."

\section{FoldDs.}

Principal Features.--Though composed of flat lying beds as a rule, the strata of the Continental interior nevertheless present evidences of orographic movements, though they may perhaps in most cases be slight. Probably the most apparent expression of this action is shown in a series of low folds the general trend of which is north and south. The most prominent of these great corrugations are five in number.

In the extreme east of the region there are the most westerly anticlines of the Appalachian system of mountains with its closely appressed folds running southwestward from New England to central Alabama. Next is a broad dome-like elevation which finds expression in the uplift of central Tennessee, the Cincinnati arch and the minor elevations of the older rocks in northern Ohio and western Ontario. The axis of this fold extends from lake Huron southward, with a little inclination to the west. Midway between the two great mountain chains of America is a third slight fold whose anticlinal axis extends approximately along the line of the Mississippi river. It is shown in the rocks of central Arkansas, in the eastern part of the Ozark uplift, in the many exposures of strata older than the Carboniferous in northeastern Missouri and eastern Iowa, in the "Isle of Wisconsin," and in some of the ancient crystallines of the lake Superior region. The outcrops of the older Paleozoic rocks along the Mississippi river cannot be regarded as due entirely to unaided erosion. Apparently the deep gorges of the great river are due partly to the results of the ordinary action of running water; partly to the result of an accelerated erosion on account of the gradual elevation of the principal line of drainage. There is evidence at hand to show that the movement, slight as it may have been, had already begun before the close of the Lower Carboniferous in the present upper Mississippi valley. The fourth fold is perhaps somewhat imperfectly defined at present, but it is indicated by a line of small areas of very ancient rocks trending northwesterly through central Texas and Indian territory, and protruding through much younger strata. The last is a series of deformations 
on the extreme west, forming the easternmost range of the Rocky mountains. The trend of the axis is southeastward.

It is a significant fact that the axes of all five of the great folds when prolonged strike approximately the same point in the Gulf of Mexico, a short distance from the mouth of the Mississippi river, a place where a maximum load of sediments from the North American continent is now being deposited; or, in other words, the axes radiate from this point.

Comparatively simple in its general geologic structure, easy of subdivision into tolerably well-defined minor groups according to lithologic features, and abundantly supplied with characteristic fossils in all its beds, the Paleozoic series of the interior basin still possesses stratigraphic phases highly complicated in their nature. It is an arrangement of strata such as might occur along the coast of any continental mass receiving sediments from numerous sources and forming very distinct interlocking beds, each of which rapidly or gradually thins out in all directions and is replaced by others. It is an arrangement which presents great difficulties to a natural geologic classification of the beds that would be applicable to all portions of the district, both on account of the vastness of the province and the multiplicity of conditions under which the depositions were made.

Minor Corrugations.-Besides the flexures just mentioned, there are in the region many smaller folds and synclines, which have a trend independent of the larger ones. These are usually grouped into series of more or less limited extent, the different series being independent of one another. Their existence has long been known, yet the extent and amplitude of none have been determined with accuracy. In Iowa a number of low folds have been recognized. Their axes have a northwestsoutheast direction in the eastern part and northeast-southwest in the western portion of the state. Several have also been made out in central Iowa. In the neighboring states similar small folds have been noted from time to time.

\section{FaUlts.}

Alleged Faulting.-In the early days of geologic exploration in the Mississippi valley, faults, many of considerable extent, were frequently reported at different places. In his canoe voyage up the Des Moines river from its mouth to the Lizard fork, near the present site of Fort Dodge, Owen recorded a number of very marked instances. Worthen, who made the same trip a decade later, also claimed to have recognized some very striking dislocations of the strata. Subsequent investigations have not only failed to substantiate the earlier observations, but have proved con- 
clusively that most if not all of the "faults" in question have no existence. A notable instance is the "great fault" at Elk Cliff, in Marion county, which Owen* reported as having a throw of more than 150 feet. Lately careful examination of the locality has shown without the slightest doubt that the abrupt change in lithologic features at this place in the short distance of a few rods is due largely to erosion during Carboniferous times. At Redrock bluff, two miles above Elk Cliff, the old steep-sided channels of erosion are upward of 100 feet in depth. Faults of 50 or 75 feet have been reported from other places in the Iowa coal-field, but in every case investigated no satisfactory evidence has been obtained to substantiate the claims.

Farther south in Missouri, on the Mississippi river above Saint Louis, the Cap-au-Grès "fault" has been estimated to have a development of more than four hundred feet. Others of minor note have also had attention called to them.

Dislocations in Iowa.-In all the Iowa coal-field less than half a dozen true faults are known to be clearly defined in surface exposures, for, as in most cases of faulting, the exact line of displacement is commonly more or less completely obscured through the weathering of the strata or by extensive superficial deposits. Ordinarily it would be impossible to recognize these faults, except as fortunate artificial excavations reveal them. The development of the coal-mining industry in the state, however, has been the means of disclosing series of small faults which would otherwise have remained forever unknown. Owing to the important rôle stratigraphic displacements play in the economy of mining, slips of only two or three feet are brought quite prominently into account. The large number and proximity of these small faults have been in some cases rather surprising, and the chief object of the present paper is to call attention to some of the dislocations as presented in the Iowa coal-field.

Normal Faults.-All the faults observed are of the normal kind, with a hade varying from a few to sixty or seventy degrees and a throw of from a few inches to several feet. The ruptures and slippings in the workable beds of the Iowa Coal Measures rarely interfere seriously with mining operations as they often do in other regions, yet their geologic import is significant. It has been only through he extensive removal of comparatively thin bads that they have been brought to light. The line of displacement as displayed in a mine entry is usually as sharply defined as if drawn with a pencil, though often theedges of the two parts are sometime,s broken. In most cases the planes of sedimentation for a few inches on each side of the fault line are bent more or less sharply upward on the down-throw side and downward on the up-throw side.

* Geol. Survey Wisconsin, Jowa and Minnesota, Philadelphia, 1852, p. 117. 
The two surfaces along the line of movement which have been rubbed together are commonly very dense, hard and highly polished, forming what is usually termed "slickensides." The common appearance of these faults as they are encountered in mining is represented in figure 1, which is taken from the Bloomfield shaft near Des Moines. It is typical of quite a large number occurring in this and other mines. Sometimes the slips are quite small (figure 2) and die out in the coal vein itself, as shown in the Thistle mine in Appanoose county. An especially interesting fault has been observed in the

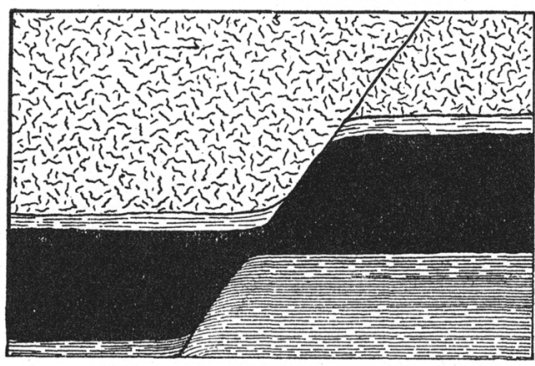

Figure 1.-Fault in Bloomfield Shaft, Des Moines, Iowa. American mine in $\mathrm{M}$ ahaska county, where the line of movement has been directed through a narrow nodular band or elongated mass of clay ironstone (figure 3 ). The line of breakage in passing from the softer to the harder layer is

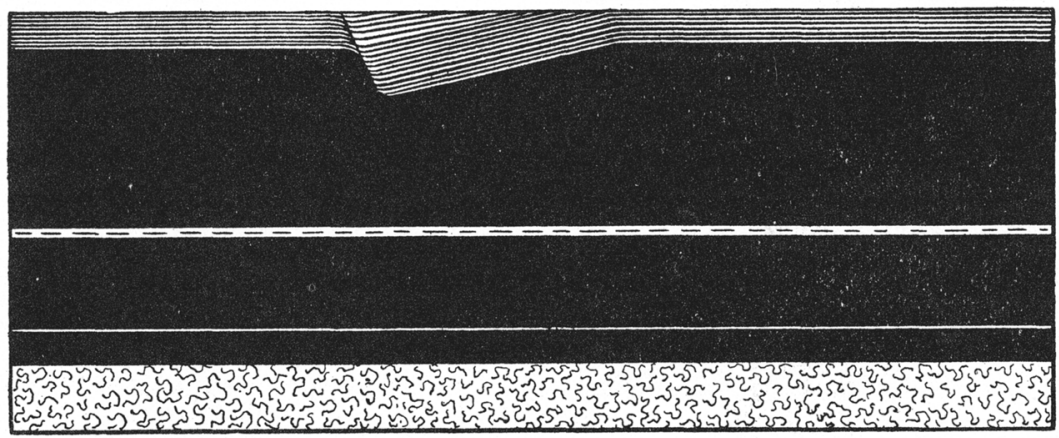

Frgure 2.-Deformation in Roof of Thistle Mine, Appanoose County, Iowa.

changed in direction, being bent toward the normal, while after passing into the coal seam again it assumes its original direction. This phenomenon is essentially the same which has been recognized in slates where hard grit bands are intercalated.

Step Faults.-Where the ordinary normal fault is repeated a number of times within a short distance the step fault is formed. Exposures of this kind are well shown in the Davison mine in Jasper county. Figure 4 represents a section through part of one of the entries, although the entire series is not here reproduced. The fall of the displacements is 
from six inches to several feet, the inclinations being about forty degrees. Another similar series occurs in the Deep Vein mine in Monroe county. In all cases the faults are practically parallel to one another. In some places the effect of the strain instead of appearing in faults is relieved

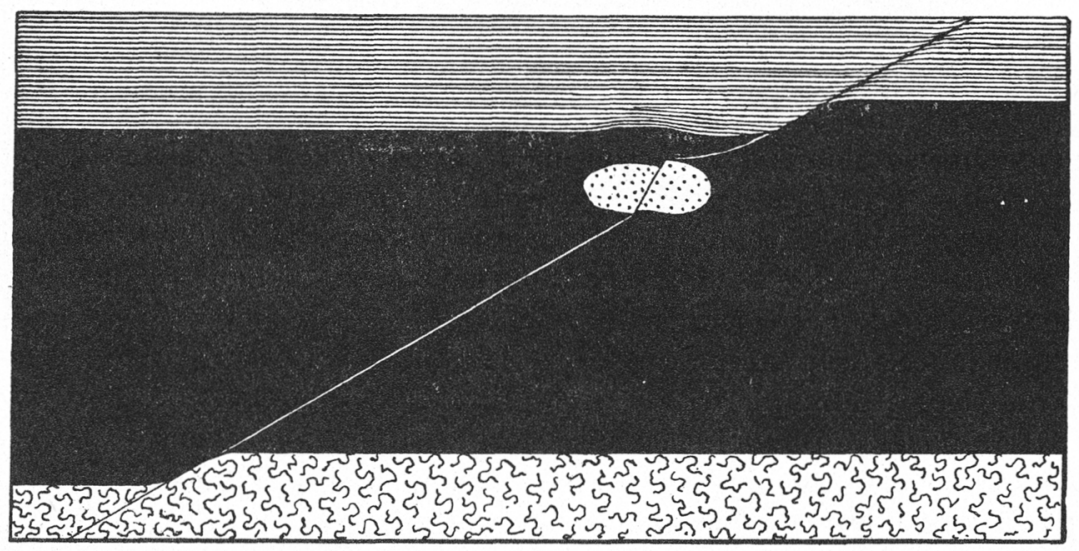

Figure 3.-Fault in American Mine, Mahaska County, Iowa.

partly by small sharp folds without direct fractures. From an examination of numbers of these small faults and of others of similar character in mountainous regions it would seem that the adjustment of tension in the earth's crust here, as in districts of greater deformation, is accomplished by means of many small slips rather than by a few large ones.

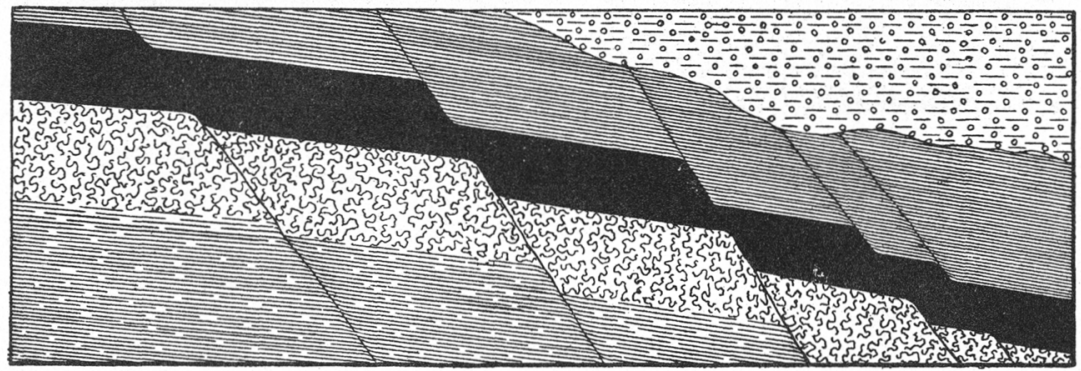

Figure 4.-Step Fault in Davison Mine, Jasper County, Iowa.

Similar faulting has been worked out in the mountain districts of California, where recently Becker has made some extended and extremely interesting observations in this direction.

Trough Faults.-A special case of the ordinary normal fault is when two slips with hades in opposite directions occur close together, allowing 
a more or less distinctly wedge-shaped portion to be displaced. These are commonly called trough faults. One observed in the Appanoose shaft in the southerm part of the state is represented in figure 5. Here

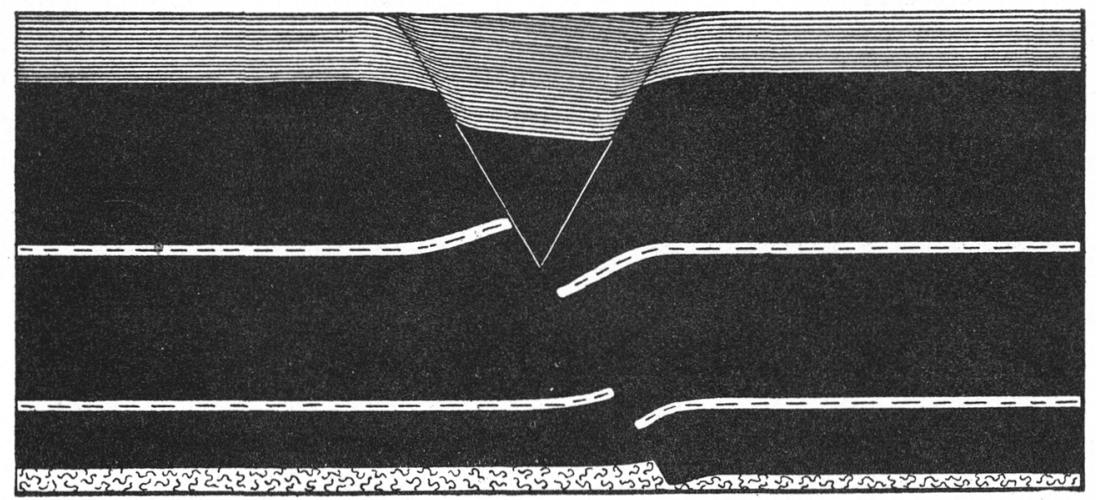

FigURE 5. - Trough Fault in Appanoose Shaft, southern Iowa.

the strain has evidently been relieved partly through a major slip and partly through a minor one.

Clay Seams.-Simple fissures or ruptures are of not infrequent occurrence in the Coal Measures of Iowa. They are merely a separation of the different parts of the vein without apparent displacement. The

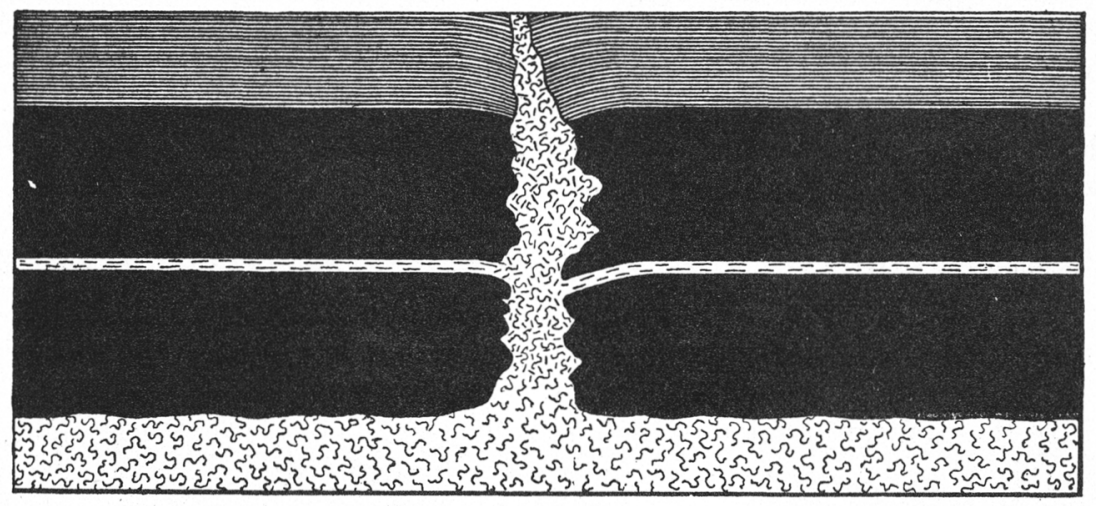

Figure 6.-Clay Fissure in Thistle Mine, Appanoose Cunnty, Iowa.

fissures are usually more or less vertical, with often very irregular borders, though sometimes they may be inclined at considerable angles. In the majority of cases clay fills the fissures which may be from a few inches to a foot or more in width, or sand may occupy all the space XXXiri-Burr. Gror, Soc. Am., Vor. 5, 1893. 
and form a compact sandstone wall. One of these from the Thistle mine in Appanoose county is shown in figure 6.

Origin of the Faults. - While many of the displacements in the region under consideration are undoubtedly due to the ordinary causes producing normal faulting, there are some cases in the Coal Measures, and perhaps these form the majority of the small slips, which owe their origin to the gradual compression of the coal beds themselves after the original vegetable accumulations had been covered by sediments. The process of compression is probably in progress at the present time, though slowly and at a greatly diminished rate compared with the former periods.

When a vegetal mass is subjected to conditions favorable to the formation of mineral fuel in the way that most of the coal beds of the upper Mississippi valley were apparently formed, there is a constant addition of sediments above, increasing the superincumbent weight until it frequently becomes something enormous; the temperature of the mass at the same time gradually rises. The heat and pressure, aided at times by other agencies perhaps, may continue to be operative for long periods, the plant accumulation in the meanwhile going successively through all stages of bituminization to the hardest anthracite or even to graphite. In the process, through the loss of water and various gases and through certain chemical reactions of the various component elements or compounds among themselves, the bulk of the mass is very greatly reduced, the amount of reduction of course depending upon the nature of the swamp materials, the degree of bituminization and method by which the loss of carbon is effected. According to the estimates of Maclaren, in one of the Scottish coal-fields, it would take nearly 2,000 acres of forest to produce an acre of coal three feet in thickness. In case of the average Iowa coal bed, it has probably taken upward of thirty feet of closely compacted material of the original woody growth to produce a seam of coal having the thickness of four and one-half feet-the mean measurement of the veins mined in the state. Ordinary anthracite probably shrinks to less than one-tenth of its original bulk in the course of its formation, so that a bed 25 feet thick may represent between 250 and 300 feet of the original mass.

In the diminution of bulk in a great lenticular deposit of vegetation, the change in dimensions is chiefly in a vertical direction. Providing the surface of the marsh were originally nearly horizontal, as probably was usually the case, the margins would remain stationary, while the center of the mass, where the contraction is naturally greatest, would be depressed below the level of the borders, producing, when fully compressed, a shallow, saucer-shaped sheet of coal. This fact is also well exhibited in the coal deposits of Iowa, especially in the case of the smaller basins; 
as, for instance, the vein displayed at the top of the Redrock sandstone quarry in Marion county.

As an example of what took place during the period when coal was forming, a case may be assumed somewhat similar to that just mentioned. Let there be imagined a swamp one-fourth to one-half a mile in diameter and 200 feet in depth ; let the swamp be filled to within a few feet of the water-level with half decayed vegetation; let the region, after this stage is reached, become one of slow subsidence, and let it be so situated as to allow the introduction into the swamp of currents, which sweep in sediments of different kinds; then the conditions of the old coal marshes are practically reproduced. If the superincumbent sediments should continue to accumulate and the peat-like mass be compressed to one-tenth or less of the original bulk the process would be almost identical with that which seems to have taken place in connection with many of the coal beds of Iowa. It being possible for the compression and diminution of bulk to take place only in one direction, that is, vertical, on account of the weight of the overlying beds, there results a broad sheet of pressed vegetal remains, thickest centrally, and becoming gradually attenuated toward the margins. During the process of compression the central part of the upper surface, which, just prior to the influx of sediments when the swamp had reached its greatest development and expansion, was on a level with the margins, is little by little depressed or bent downward as the plant remains are more and more compacted. At the end of the process the upper surface of the plant mass at the center of the basin will be from 175 to 185 feet below its original level. In the particular case assumed this would be a slope of about 1 in 13 in all directions toward the center, or a dip of $5^{\circ}$, nearly. Conceiving this area to be covered to a considerable depth with other beds, the phenomena becomes practically identical with what is now observed everywhere in connection with the coal beds. When the lower and more extensive seams of the Coal Measures are constantly contracting in bulk the series higher up and the associated strata, in responding to the effects of gravity, become undulatory or give rise to a series of small slips. This fact may, after more extended investigation, come to have an important economic bearing in the detection of valuable coal beds at lower levels than are commonly worked or prospected.

\section{SUMmakY.}

From the foregoing it would appear that-

In the upper Mississippi valley there exist faults, the number and extent of which has never been fully realized. 
242 C. R. KEYES-CRUSTAL ADJUSTMENT IN MISSISSIPPI VALLEY.

In the Coal Measures of some parts of the region the slips are usually of small extent, but much more numerous than has been generally suspected heretofore.

There are also numerous dislocations, but without marked displacement.

In the case of many of the small faults the stresses may have been superinduced by the diminution in bulk of lenticular coal beds at horizons somewhat lower than those in which they occur. 